\title{
Characterization and assessment of potential environmental risk of tailings stored in seven impoundments in the Aries river basin, Western Romania
}

Erika Levei ${ }^{1 *}$, Tiberiu Frentiu ${ }^{2}$, Michaela Ponta ${ }^{2}$, Claudiu Tanaselia ${ }^{1}$ and Gheorghe Borodi ${ }^{3}$

\begin{abstract}
Background: The objective of this study was to examine the potential environmental risk of tailings resulted after precious and base metal ores processing, stored in seven impoundments located in the Aries river basin, Romania. The tailings were characterized by mineralogical and elemental composition, contamination indices, acid rock drainage generation potential and water leachability of hazardous/priority hazardous metals and ions. Multivariate statistical methods were used for data interpretation.

Results: Tailings were found to be highly contaminated with several hazardous/priority hazardous metals (As, Cu, $\mathrm{Cd}, \mathrm{Pb}$ ), and pose potential contamination risk for soil, sediments, surface and groundwater. Two out of the seven studied impoundments does not satisfy the criteria required for inert wastes, shows acid rock drainage potential and thus can contaminate the surface and groundwater. Three impoundments were found to be highly contaminated with $\mathrm{As}, \mathrm{Pb}$ and $\mathrm{Cd}$, two with $\mathrm{As}$ and other two with $\mathrm{Cu}$. The tailings impoundments were grouped based on the enrichment factor, geoaccumulation index, contamination factor and contamination degree of 7 hazardous/priority hazardous metals ( $\mathrm{As}, \mathrm{Cd}, \mathrm{Cr}, \mathrm{Cu}, \mathrm{Ni}, \mathrm{Pb}, \mathrm{Zn}$ ) considered typical for the studied tailings. Principal component analysis showed that $47 \%$ of the elemental variability was attributable to alkaline silicate rocks, $31 \%$ to acidic S-containing minerals, $12 \%$ to carbonate minerals and 5\% to biogenic elements. Leachability of metals and ions was ascribed in proportion of $61 \%$ to silicates, $11 \%$ to acidic minerals and $6 \%$ to the organic matter. A variability of $18 \%$ was attributed to leachability of biogenic elements $\left(\mathrm{Na}, \mathrm{K} \mathrm{Cl}^{-}, \mathrm{NO}_{3}^{-}\right)$with no potential environmental risk. Pattern recognition by agglomerative hierarchical clustering emphasized the grouping of impoundments in agreement with their contamination degree and acid rock drainage generation potential.
\end{abstract}

Conclusions: Tailings stored in the studied impoundments were found to be contaminated with some hazardous/ priority hazardous metals, fluoride and sulphate and thus presents different contamination risk for the environment. A long term monitoring program of these tailings impoundments and the expansion of the ecologization measures in the area is required.

Keywords: Tailings, Hazardous/priority hazardous metal, Acid rock drainage, Environmental risk, Multivariate statistics

\footnotetext{
* Correspondence: erika.levei@icia.ro

${ }^{1}$ INCDO-INOE 2000, Research Institute for Analytical Instrumentation, 67

Donath, 400293, Cluj-Napoca, Romania

Full list of author information is available at the end of the article
} 


\section{Background}

Exploitation of mineral resources containing base and precious metals is one of the main activities that have contributed to the development of humanity. In the same time, mining has a negative reputation because of the large amounts of associated wastes discharged in tailings impoundments, which has caused damages to the surrounding mining areas by soil, water and air pollution [1]. The tailings exposed to weathering are important sources of Acid Rock Drainage (ARD), which contaminates the environment with metals, non-metals and sulphate anions as a result of the sulphide oxidation and leaching process [2-7].

Although mining activity stopped in certain area, the potential risk of environment contamination still exists through the vast quantities of waste stored in tailings impoundments. The ARD generated by tailings represents in case of accidents the main pollution source of natural watercourses, sometimes with cross-border effects. It can be mentioned the accidents that occurred in January 2000 in Baia Mare and March 2000 in Baia Borsa in northern Romania, when more than $200000 \mathrm{~m}^{3}$ of waste water containing metals and cyanide from two tailings impoundments reached the Somes and Viseu rivers and finally the Danube via the Tisa river $[8,9]$. As a consequence of such accidents, elemental composition and mineralogical characterization of mining waste in order to identify hazardous/priority hazardous metals and reactive sulphides is required for the assessment of potential environmental risk [10-16].

The aim of this work was to characterize and evaluate the potential environmental risk of tailings impoundments located in the Aries river basin, Alba County, the Apuseni Mountains, Romania, related to porphyry copper and precious metals mining. Several complementary approaches were considered for this purpose. The mineralogical and elemental ( $\mathrm{Al}, \mathrm{Fe}, \mathrm{Ca}, \mathrm{K}, \mathrm{Mg}, \mathrm{Na}, \mathrm{Mn}$, $\mathrm{Ba}, \mathrm{Zn}, \mathrm{Pb}, \mathrm{Cu}, \mathrm{Ni}, \mathrm{Cr}, \mathrm{As}, \mathrm{Cd}, \mathrm{Co}, \mathrm{Sr}, \mathrm{Ti}, \mathrm{V}, \mathrm{W}, \mathrm{Ag}$, $\mathrm{Au}, \mathrm{S})$ composition of tailings were determined and the ARD generation potential was assessed using Net Neutralization Potential (NNP). It was studied the leachability of hazardous (Ag, As, Ba, Co, Cr, Cu, Ti, V, Zn)/ priority hazardous $(\mathrm{Cd}, \mathrm{Ni}, \mathrm{Pb})$ metals and several ions $\left(\mathrm{F}^{-}, \mathrm{Cl}^{-}, \mathrm{NO}_{3}^{-}, \mathrm{SO}_{4}^{2-}, \mathrm{NH}_{4}^{+}\right)$. The term "hazardous/priority hazardous metals" was used throughout this paper considering their toxicity and classification in these two groups according to [17]. The terms "heavy metal" and "potentially toxic metal" were avoided as they have ambiguous uses in environmental quality assessments [18]. Tailings contamination was characterized by several indices calculated for seven hazardous/priority hazardous metals (As, Cd, Cr, Cu, Ni, Pb, Zn). The selection of these metals was made in accordance with Hakanson [19], thus for the assessment of contamination risk the typical parameters for the studied area were considered and not all toxic substances. Generally, these are metals with similar occurrence and behaviour under comparable conditions. Although, Ag has a similar toxicity with that of $\mathrm{Cr}$, it was not considered in the calculus of contamination indices because the statistical analysis revealed that precious metals have low influence in describing the variability of tailings composition. The contamination risk of tailings for soil, river sediment, river and groundwater was assessed by comparing the determined metal and ion contents with the corresponding limit values. The contribution of pollutants to variability of tailings composition was evaluated using Principal Component Analysis (PCA). The impoundments were grouped according to the contamination degree and ARD generation potential using Agglomerative Hierarchical Clustering (AHC).

\section{Results and discussion Site description}

Romania has a long mining history of base $(\mathrm{Cu}, \mathrm{Cd}, \mathrm{Pb}$, $\mathrm{Zn)}$ and precious metals, most centres and tailings impoundments being located in the north of the country (Maramures County) or in the west in the Apuseni Mountains (Alba and Hunedoara Counties). The southern part of the Apuseni Mountains is recognized for its $\mathrm{Au}$ and Ag deposit within the Golden Quadrangle as well as the Rosia Poieni porphyry copper deposit, which together led to the development of prosperous mining activities. Besides the economic importance, the Apuseni Mountains zone is known for the tourism potential represented by several natural reservations and caves [20].

In the Aries river basin with an area of $3000 \mathrm{~km}^{2}$ in the Alba County there are several open pits and underground mines as well as the related tailings impoundments storing tailings from dressing of non-ferrous copper ores and precious metals. Seven tailings impoundments put into operation after 1963 with a surface of 444 ha and storing about 100 million $\mathrm{m}^{3}$ of tailings were considered in this study. The main characteristics of these impoundments and their locations are provided in Table 1 and Figure 1. Currently five of the seven are going green, whereas two (Stefanca and Sesei) are still in use for storing waste from the processing of the Rosia Poieni porphyry copper deposit mined in open pit [21].

There are few published data on the characterization and assessment of potential environmental risk of tailings in the area under study. Two papers should be mentioned, namely that of Sima et al. [3] who characterized the Mialu and Ribita tailings impoundments located in the Certej and Crisul Alb floodplains and that of Friedel et al. [22] about the influence of the Stefanca and Sesei impoundments on groundwater. The drainage, collection and leachate treatment systems of the tailings 
Table 1 Characteristics of the tailings impoundments under study located in the Aries river basin

\begin{tabular}{|c|c|c|c|c|c|c|c|}
\hline Impoundment & River & $\begin{array}{l}\text { Year of putting } \\
\text { into operation }\end{array}$ & Current status & Type & $\begin{array}{l}\text { Surface } \\
\text { (ha) }\end{array}$ & $\begin{array}{l}\text { Dam height } \\
(\mathrm{m})\end{array}$ & $\begin{array}{l}\text { Deposit volume } \\
\left(\mathrm{mil} \mathrm{m}^{3}\right)\end{array}$ \\
\hline Saliste & Abrud & 1986 & Closed since 2004 , going green & Valley deposit & 18.5 & 87 & 6.60 \\
\hline Gura Rosiei & Abrud & 1967 & Closed, going green & Slope deposit & 23.0 & 44 & 5.80 \\
\hline Stefanca & Stefanca & 1993 & In operation (storage stopped) & Valley deposit & 50.7 & 85 & 11.0 \\
\hline Sesei & Sesei & 1985 & In operation & Valley deposit & 330 & 100 & 66.0 \\
\hline$\overline{\text { Cutii }}$ & Harmaneasa & 1976 & Closed since 2002, going green & Valley deposit & 4.8 & 74 & 1.62 \\
\hline Sartas & Sartas & 1993 & Closed since 2005 , going green & Valley deposit & 6.0 & 78 & 2.86 \\
\hline Brazesti & Aries & 1963 & Going green & Slope deposit & 10.7 & 42 & 3.47 \\
\hline
\end{tabular}

impoundments under study work improperly or are even missing in some cases. Consequently, they could pose potential risk of contamination for the environment in the Aries river basin.

\section{Mineralogical composition}

Abundance of mineralogical species in tailings is summarized in Table 2. The mineralogical composition is dominated by primary minerals belonging to oxide (quartz) and aluminosilicate groups. The identified minor minerals were reactive sulphide and sulphate, which promote generation of ARD and carbonates with neutralization property. Traces of minerals containing As, $\mathrm{Ba}, \mathrm{Mn}, \mathrm{Pb}, \mathrm{Zn}$ were also identified.

\section{Elemental composition of tailings and leachability of metals and ions}

The total and the water leachable metals and ions content at a solid-to-water ratio of 1:10 are presented in Table 3. Data reveal high differences from one impoundment to another in terms of total contents and water mobility of hazardous (As, $\mathrm{Cu}, \mathrm{Cr}, \mathrm{Zn}$ )/priority hazardous

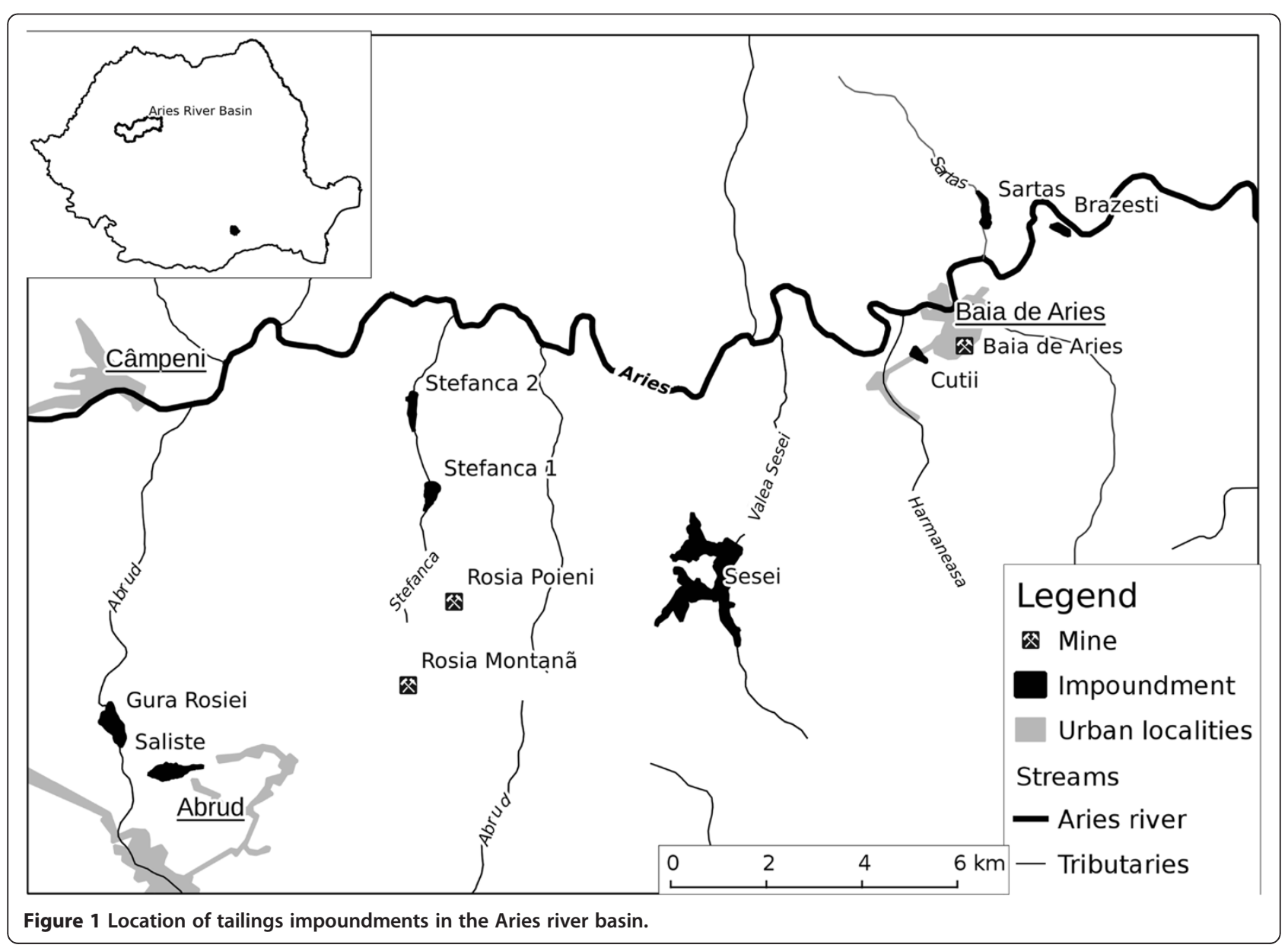


Table 2 Mineralogical composition of tailings

\begin{tabular}{|c|c|c|c|c|c|c|c|c|c|}
\hline \multirow[t]{2}{*}{ Mineral group } & \multirow[t]{2}{*}{ Mineral species } & \multirow[t]{2}{*}{ Chemical formula } & \multicolumn{7}{|c|}{ Impoundment } \\
\hline & & & Saliste & Gura Rosiei & Stefanca & Sesei & Cutii & Sartas & Brazesti \\
\hline oxides & quartz & $\mathrm{SiO}_{2}$ & ++ & ++ & ++ & ++ & ++ & + & ++ \\
\hline \multirow[t]{6}{*}{ silicates } & albite & $\mathrm{NaAlSi}_{3} \mathrm{O}_{8}$ & ++ & & + & + & & & ++ \\
\hline & muscovite & $\mathrm{KAI} 2\left(\mathrm{Si}_{3} \mathrm{Al}\right) \mathrm{O}_{10}(\mathrm{OH}, \mathrm{F})_{2}$ & & & & + & + & ++ & + \\
\hline & orthoclase & $\mathrm{AlKSi}_{3} \mathrm{O}_{8}$ & ++ & ++ & & & + & & \\
\hline & biotite & $\mathrm{NaFeKMgTiSi}_{3} \mathrm{O}_{12}$ & & + & + & & \pm & ++ & \\
\hline & feldspar & $\mathrm{Al}_{2} \mathrm{CaSr} \mathrm{O}_{8} \mathrm{Si}_{2}$ & & & \pm & & & & + \\
\hline & anorthoclase & $\mathrm{AlCaKNaO}_{8} \mathrm{Si}_{3}$ & \pm & & ++ & ++ & & + & \\
\hline \multirow[t]{5}{*}{ sulphides } & chalcopyrite & $\mathrm{CuFeS}_{2}$ & & & \pm & & \pm & \pm & \pm \\
\hline & pyrite & $\mathrm{FeS}_{2}$ & \pm & & & & \pm & \pm & \\
\hline & pyrrhotite & $\mathrm{Fe}_{9} \mathrm{~S}_{10}$ & & \pm & & & \pm & & \pm \\
\hline & sphalerite & ZnS & & & & & & \pm & \\
\hline & galena & $\mathrm{PbS}$ & & & & & \pm & \pm & \pm \\
\hline \multirow[t]{4}{*}{ sulphates } & jarosite & $\mathrm{KFe}_{3}\left(\mathrm{SO}_{4}\right)_{2}(\mathrm{OH})_{6}$ & & & & & \pm & + & \\
\hline & iron sulphate & $\mathrm{Fe}_{2}\left(\mathrm{SO}_{4}\right)_{3}$ & & & + & + & & & \\
\hline & gypsum & $\mathrm{CaSO}_{4}$ & & & & & \pm & + & \\
\hline & anglesite & $\mathrm{PbSO}_{4}$ & & & & & \pm & \pm & \\
\hline \multirow[t]{5}{*}{ carbonates } & eitelite & $\mathrm{Na}_{2} \mathrm{Mg}\left(\mathrm{CO}_{3}\right)_{2}$ & & & \pm & & & & + \\
\hline & baritocalcite & $\mathrm{BaCa}\left(\mathrm{CO}_{3}\right)_{2}$ & & & + & \pm & & & \\
\hline & calcite & $\mathrm{CaCO}_{3}$ & & & \pm & \pm & & & + \\
\hline & rhodochrosite & $\mathrm{MnCO} 3$ & & & & & & \pm & \\
\hline & dolomite & $\mathrm{CaMg}\left(\mathrm{CO}_{3}\right)_{2}$ & & + & & & & & + \\
\hline \multirow[t]{2}{*}{ arsenic minerals } & wilhelmkleinite & $\mathrm{As}_{2} \mathrm{Fe}_{2} \mathrm{Zn} \mathrm{O} \mathrm{O}_{8}(\mathrm{OH})_{2}$ & & \pm & \pm & & & & \pm \\
\hline & potassium hydroxo pentafluoro arsenate & $\mathrm{AsF}_{5} \mathrm{~K}(\mathrm{OH})$ & & & & & & & \pm \\
\hline
\end{tabular}

$(++)$ - major (20-50\%); (+) - minor (5-20\%); ( \pm - - trace $(<5 \%)$.

$(\mathrm{Cd}, \mathrm{Pb}, \mathrm{Ni})$ metals as well as ions. The mobilization of the leaching fraction by weathering processes may pose a major environmental hazard.

\section{Enrichment factors and contamination degree with hazardous/priority hazardous metals}

In order to assess the extent of tailings contamination the following indices were calculated for seven metals $(\mathrm{Pb}, \mathrm{Cu}, \mathrm{Zn}, \mathrm{As}, \mathrm{Cd}, \mathrm{Ni}, \mathrm{Cr})$ : enrichment factor $\left(\mathrm{E}_{\mathrm{f}}\right)$ according to Sinex and Helz [23], geoaccumulation index $\left(\mathrm{I}_{\text {geo }}\right)$, introduced by Muller [24], and contamination factor $\left(\mathrm{C}_{\mathrm{f}}\right)$ and contamination degree $\left(\mathrm{C}_{\mathrm{d}}\right)$ according to Hakanson [19]. The $C_{d}$ levels resulted by summing the $C_{f}$ values of metals served to classify tailings on different contamination levels. For calculation of indices, as reference, was used the natural background levels of metals in the upper continental crust: $\mathrm{Pb} \mathrm{20}$, $\mathrm{Cu}$ 25, Zn 71, As 1.5, Cd 0.098, Ni 20, Cr 35 and Fe $35000 \mathrm{mg} \mathrm{kg}^{-1}$ according to Taylor and McLeenan [25].

Contamination indices and ranking of tailings from the impoundments under study are given in Table 4. Although concentration of metals in tailings are too low to be today economically attractive for recovery purpose, some hazardous/priority hazardous metals exhibit an extremely severe enrichment $\left(\mathrm{E}_{\mathrm{f}}\right.$ increases in the order $\mathrm{Cd}$ $<\mathrm{Pb}<\mathrm{Cu}<\mathrm{As}$ ) compared to the continental crust and can be important contamination sources for soil and sediment.

Tailings of all seven impoundments present a very high contamination degree with hazardous/priority hazardous metals increasing in the order Stefanca $<$ Gura Rosiei < Sesei $<$ Saliste $<$ Cutii $<$ Sartas $<$ Brazesti. The values of contamination factors reveal qualitative differences among tailings impoundments, thus Stefanca and Sesei exhibit very high contamination with $\mathrm{Cu}$, Saliste with As, Gura Rosiei with $\mathrm{Cd}$ and As, Cutii with $\mathrm{Pb}$ and $\mathrm{As}$, while Sartas and Brazesti with $\mathrm{Cd}, \mathrm{Pb}$ and $\mathrm{As}$.

\section{Environmental contamination risk following ARD generation}

Detection by X-ray diffraction (XRD) of primary minerals as sulphide and secondary minerals as sulphate indicates that tailings in these impoundments are still reactive exhibiting potential contamination risk through ARD generation. Several features connected to the ARD generation potential for the tailings impoundments under 
Table 3 Total content of metals and the leached fraction of metals and ions by water

Parameter Impoundment

\begin{tabular}{|c|c|c|c|c|c|c|c|c|c|c|c|c|c|c|}
\hline & \multicolumn{2}{|l|}{ Saliste } & \multicolumn{2}{|c|}{ Gura Rosiei } & \multicolumn{2}{|c|}{ Stefanca } & \multicolumn{2}{|l|}{ Sesei } & \multicolumn{2}{|l|}{ Cutii } & \multicolumn{2}{|l|}{ Sartas } & \multicolumn{2}{|c|}{ Brazesti } \\
\hline & $\frac{\text { Total }}{\mathrm{mg} \mathrm{kg}^{-1}}$ & Leached & Total & Leached & Total & Leached & Total & Leached & Total & Leached & Total & Leached & Total & Leached \\
\hline $\mathrm{Al}$ & 1810 & 10.1 & 2670 & 2.25 & 15600 & 17.6 & 13000 & 4.25 & 1530 & 77.6 & 5580 & 217 & 3080 & 2.27 \\
\hline $\mathrm{Fe}$ & 9350 & 10.4 & 4650 & 1.1 & 13300 & 0.06 & 15700 & 2.2 & 15800 & 403 & 15600 & 110 & 13800 & $\underline{0.06}$ \\
\hline$\overline{M n}$ & 55.0 & 1.7 & 83.0 & 0.93 & 482 & 0.03 & 589 & 0.15 & 84.0 & 13.6 & 285 & 75.0 & 420 & 0.11 \\
\hline $\mathrm{Ba}$ & 103 & 0.06 & 47.5 & 0.07 & 120 & 0.27 & 144 & 0.240 & 64.2 & 0.120 & 114 & 0.160 & 72.1 & 0.090 \\
\hline $\mathrm{Zn}$ & 185 & 4.6 & 46.0 & 0.60 & 115 & 0.08 & 109 & 0.520 & 204 & 14.2 & 401 & 45.2 & 330 & 0.160 \\
\hline $\mathrm{Pb}$ & 117 & 0.049 & 115 & 0.051 & 25.4 & 0.009 & 31.3 & 0.080 & 528 & 0.520 & 649 & 0.540 & 551 & 0.043 \\
\hline $\mathrm{Cu}$ & 15.9 & 0.563 & 4.8 & 0.094 & 579 & 0.037 & 850 & 0.355 & 107 & 4.89 & 133 & 9.19 & 65.7 & 0.021 \\
\hline $\mathrm{Ni}$ & 2.0 & 0.165 & 1.0 & 0.044 & 3.4 & 0.05 & 1.8 & 0.044 & 1.8 & 0.48 & 11.6 & 1.57 & 5.2 & 0.059 \\
\hline $\mathrm{Cr}$ & 2.5 & 0.166 & 1.0 & 0.021 & 4.1 & 0.015 & 3.4 & 0.057 & 2.4 & 0.283 & 9.8 & 0.300 & 4.3 & 0.050 \\
\hline As & 101 & 0.031 & 50.8 & 0.034 & 5.5 & 0.021 & 7.4 & 0.137 & 483 & 0.560 & 575 & 0.530 & 655 & 0.600 \\
\hline $\mathrm{Cd}$ & 0.60 & 0.050 & 0.10 & 0.012 & 0.20 & 0.01 & 0.40 & 0.013 & 0.40 & 0.080 & 1.5 & 0.351 & 1.6 & 0.010 \\
\hline $\mathrm{Co}$ & 0.30 & 0.023 & 0.10 & 0,011 & 6.2 & 0.001 & 10.2 & 0.002 & 0.60 & 0.148 & 2.2 & 0.718 & 3.3 & 0.001 \\
\hline $\mathrm{V}$ & 37.0 & $0.002_{-}^{a}$ & 13.8 & $\underline{0.002}$ & 96.8 & 0.002 & 179 & $\underline{0.002}$ & 11.2 & 0.002 & 12.8 & 0.002 & 7.7 & $\underline{0.002}$ \\
\hline $\mathrm{Ag}$ & 10.5 & $\underline{0.001}$ & 8.0 & $\underline{0.001}$ & 0.30 & 0.001 & 0.50 & $\underline{0.001}$ & 5.3 & $\underline{0.001}$ & 5.8 & 0.001 & 2.2 & $\underline{0.001}$ \\
\hline $\mathrm{F}-$ & - & 1.8 & - & $\underline{0.15}$ & - & 2.4 & - & 1.4 & - & 11.0 & - & 13.0 & - & 0.80 \\
\hline $\mathrm{Cl}^{-}$ & - & 9.3 & - & 5.3 & - & 25.0 & - & 0.400 & - & 17.0 & - & 9.3 & - & 3.4 \\
\hline $\mathrm{SO}_{4}^{2-}$ & - & 700 & - & 46.4 & - & 1100 & - & 217 & - & 17000 & - & 17000 & - & 240 \\
\hline $\mathrm{NO}_{3}^{-}$ & - & $\underline{0.15}$ & - & 0.8 & - & 1.9 & - & 0.15 & - & $\underline{0.15}$ & - & $\underline{0.15}$ & - & $\underline{0.15}$ \\
\hline $\mathrm{NH}_{4}^{+}$ & - & 3.5 & - & 5.5 & - & 3.5 & - & 4.2 & - & 6.2 & - & 5.2 & - & 2.7 \\
\hline
\end{tabular}

${ }^{a}$ half of the detection limit. 
Table 4 Contamination indices and ranking of tailings impoundments located in the Aries river basin ${ }^{a}$

\begin{tabular}{|c|c|c|c|c|c|c|c|}
\hline \multicolumn{8}{|c|}{ Enrichment factor $\left(E_{f}\right)$} \\
\hline Impoundment & $\begin{array}{l}\text { No } \\
\left(0<E_{f} \leq 1\right)\end{array}$ & $\begin{array}{l}\text { Minor } \\
\left(1<E_{f} \leq 3\right)\end{array}$ & $\begin{array}{l}\text { Moderate } \\
\left(3<E_{f} \leq 5\right)\end{array}$ & $\begin{array}{l}\text { Moderately severe } \\
\left(5<\mathrm{E}_{\mathrm{f}} \leq 10\right)\end{array}$ & $\begin{array}{l}\text { Severe } \\
\left(10<\mathrm{E}_{\mathrm{f}} \leq 25\right)\end{array}$ & $\begin{array}{l}\text { Very severe } \\
\left(25<\mathrm{E}_{\mathrm{f}} \leq 50\right)\end{array}$ & $\begin{array}{l}\text { Extremely severe } \\
\left(E_{f}>50\right)\end{array}$ \\
\hline Saliste & $\mathrm{Ni}<\mathrm{Cr}$ & $\mathrm{Cu}$ & - & $\mathrm{Zn}(9.8)$ & $\mathrm{Pb}(22), \mathrm{Cd}(23)$ & - & $\operatorname{As}(251)$ \\
\hline Gura Rosiei & $\mathrm{Cr}<\mathrm{Ni}$ & $\mathrm{Cu}$ & $\mathrm{Zn}$ & $\mathrm{Cd}(7.7)$ & - & $\mathrm{Pb}(43)$ & $\operatorname{As}(255)$ \\
\hline Stefanca & $\mathrm{Cr}<\mathrm{Ni}$ & - & $\mathrm{Pb}<\mathrm{Zn}$ & $\mathrm{Cd}(5.4), \operatorname{As}(9.6)$ & - & - & $\mathrm{Cu}(61)$ \\
\hline Sesei & $\mathrm{Ni}<\mathrm{Cr}$ & - & $\mathrm{Pb}<\mathrm{Zn}$ & $\mathrm{Cd}(9.1)$ & $\operatorname{As}(11)$ & - & $\mathrm{Cu}(76)$ \\
\hline$\overline{\text { Cutii }}$ & $\mathrm{Ni}<\mathrm{Cr}$ & - & - & $\begin{array}{l}\mathrm{Zn}(6.4), \mathrm{Cd}(9.1), \mathrm{Cu} \\
(9.5)\end{array}$ & - & - & $\mathrm{Pb}(59), \mathrm{As}(715)$ \\
\hline Sartas & $\mathrm{Cr}$ & $\mathrm{Ni}$ & - & - & $\mathrm{Cu}(12), \mathrm{Zn}(13)$ & - & $\begin{array}{l}\mathrm{Cd}(34), \mathrm{Pb}(73), \\
\mathrm{As}(860)\end{array}$ \\
\hline Brazesti & $\mathrm{Cr}<\mathrm{Ni}$ & - & - & $\mathrm{Cu}(6.9)$ & $\mathrm{Zn}(12)$ & $\mathrm{Cd}(41)$ & $\mathrm{Pb}(70), \mathrm{As}(1100)$ \\
\hline \multicolumn{8}{|c|}{ Geoaccumulation index $\left(I_{\text {geo }}\right)$} \\
\hline Impoundment & $\begin{array}{l}\text { Practically } \\
\text { unpolluted } \\
\left(I_{\text {geo }}<0\right)\end{array}$ & $\begin{array}{l}\text { Unpolluted to } \\
\text { moderately } \\
\text { polluted } \\
\left(0<I_{\text {geo }} \leq 1\right)\end{array}$ & $\begin{array}{l}\text { Moderately } \\
\text { polluted } \\
\left(1<\mathrm{I}_{\mathrm{geo}} \leq 2\right)\end{array}$ & $\begin{array}{l}\text { Moderately to } \\
\text { heavily polluted } \\
(2<\text { I geo } \leq 3)\end{array}$ & $\begin{array}{l}\text { Heavily } \\
\text { polluted } \\
\left(3<\mathrm{I}_{\mathrm{geo}} \leq 4\right)\end{array}$ & $\begin{array}{l}\text { Heavily to } \\
\text { extremely } \\
\text { polluted } \\
(4<\text { Igeo } \leq 5) \\
\end{array}$ & $\begin{array}{l}\text { Extremely } \\
\text { polluted } \\
\left(\mathrm{I}_{\text {geo }}>5\right)\end{array}$ \\
\hline Saliste & $\mathrm{Cr}<\mathrm{Ni}<\mathrm{Cu}$ & $\mathrm{Zn}$ & $\begin{array}{l}\mathrm{Pb}(2.0), \mathrm{Cd} \\
(2.0)\end{array}$ & - & - & - & $\operatorname{As}(5.5)$ \\
\hline Gura Rosiei & $\begin{array}{l}\mathrm{Cr}<\mathrm{Ni}<\mathrm{Cu}<\mathrm{Zn}< \\
\mathrm{Cd}\end{array}$ & - & $\mathrm{Pb}(1.9)$ & - & - & $\operatorname{As}(4.5)$ & - \\
\hline Stefanca & $\mathrm{Cr}<\mathrm{Ni}<\mathrm{Pb}$ & $\mathrm{Zn}<\mathrm{Cd}$ & $\operatorname{As}(1.3)$ & - & $\mathrm{Cu}(3.9)$ & - & - \\
\hline Sesei & $\mathrm{Ni}<\mathrm{Cr}$ & $\mathrm{Zn}<\mathrm{Pb}$ & $\begin{array}{l}\mathrm{Cd}(1.5), \mathrm{As} \\
(1.7)\end{array}$ & - & - & $\mathrm{Cu}(4.5)$ & - \\
\hline Cutii & $\mathrm{Ni}<\mathrm{Cr}$ & $\mathrm{Zn}$ & $\begin{array}{l}\mathrm{Cd}(1.4), \mathrm{Cu} \\
(1.5)\end{array}$ & - & - & $\mathrm{Pb}(4.1)$ & $\operatorname{As}(7.8)$ \\
\hline Sartas & $\mathrm{Cr}<\mathrm{Ni}$ & & $\begin{array}{l}\mathrm{Cu}(1.8), \mathrm{Zn} \\
(1.9)\end{array}$ & - & $\mathrm{Cd}(3.4)$ & $\mathrm{Pb}(4.4)$ & $\mathrm{As}(8.0)$ \\
\hline Brazesti & $\mathrm{Cr}<\mathrm{Ni}$ & $\mathrm{Cu}$ & $\mathrm{Zn}(1.6)$ & - & $\mathrm{Cd}(3.4)$ & $\mathrm{Pb}(4.2)$ & $\mathrm{As}(8.2)$ \\
\hline \multicolumn{8}{|c|}{ Contamination factor $\left(C_{f}\right)$} \\
\hline Impoundment & $\begin{array}{l}\text { Low } \\
\left(C_{f}<1\right)\end{array}$ & $\begin{array}{l}\text { Moderate } \\
\left(1<C_{f} \leq 3\right)\end{array}$ & & $\begin{array}{l}\text { Considerable } \\
\left(3<\mathrm{C}_{\mathrm{f}} \leq 6\right)\end{array}$ & $\begin{array}{l}\text { Very high } \\
\left(C_{f}>6\right)\end{array}$ & & \\
\hline Saliste & $\mathrm{Ni}<\mathrm{Cr}<\mathrm{Cu}$ & $\mathrm{Zn}(2.6)$ & & $\mathrm{Pb}(5.9)$ & $\mathrm{Cd}(6.1), \operatorname{As}(67)$ & & \\
\hline Gura Rosiei & $\begin{array}{l}\mathrm{Cr}<\mathrm{Ni}<\mathrm{Cu}<\mathrm{Zn}< \\
\mathrm{Cd}\end{array}$ & - & & $\mathrm{Pb}(5.8)$ & $\mathrm{As}(34)$ & & \\
\hline Stefanca & $\mathrm{Cr}<\mathrm{Ni}$ & $\mathrm{Pb}(1.3), \mathrm{Zn}(1.4), \mathrm{C}$ & $\mathrm{Cd}(2.0)$ & $\operatorname{As}(3.7)$ & $\mathrm{Cu}(23)$ & & \\
\hline Sesei & $\mathrm{Ni}<\mathrm{Cr}$ & $\mathrm{Zn}(1.5), \mathrm{Pb}(1.6)$ & & $\mathrm{Cd}(4.1), \operatorname{As}(4.9)$ & $\mathrm{Cu}(34)$ & & \\
\hline Cutii & $\mathrm{Ni}<\mathrm{Cr}$ & $\mathrm{Zn}(2.9)$ & & $\mathrm{Cd}(4.1), \mathrm{Cu}(4.3)$ & $\mathrm{Pb}(26), \mathrm{As}(321)$ & & \\
\hline Sartas & $\mathrm{Cr}<\mathrm{Ni}$ & - & & $\mathrm{Cu}(5.3), \mathrm{Zn}(5.6)$ & $\mathrm{Cd}(15), \mathrm{Pb}(32)$, & As(384) & \\
\hline Brazesti & $\mathrm{Cr}<\mathrm{Ni}$ & $\mathrm{Cu}(2.6)$ & & $\mathrm{Zn}(4.6)$ & $\mathrm{Cd}(16), \mathrm{Pb}(28)$, & As(437) & \\
\hline \multicolumn{8}{|c|}{ Contamination degree $\left(C_{d}\right)$} \\
\hline & $\begin{array}{l}\text { Low } \\
\left(C_{d}<8\right)\end{array}$ & $\begin{array}{l}\text { Moderate } \\
\left(8<C_{d} \leq 16\right)\end{array}$ & & $\begin{array}{l}\text { Considerable } \\
\left(16<C_{d} \leq 32\right)\end{array}$ & $\begin{array}{l}\text { Very high } \\
\left(C_{d}>32\right)\end{array}$ & & \\
\hline Impoundment & - & - & - & & $\begin{array}{l}\text { Stefanca (32), } \\
\text { Cutii (360), Sar }\end{array}$ & $\begin{array}{l}\text { ura Rosiei, (42), } \\
\text { as (443), Brazest }\end{array}$ & $\begin{array}{l}\text { esei (46), Saliste (83), } \\
(488)\end{array}$ \\
\hline
\end{tabular}

${ }^{a}$ based on seven typical metals for the studied area.

study are presented in Table 5. According to NNP values, tailings from Sartas and Cutii impoundments are undoubted sources of ARD as a result of the high $\mathrm{S}$ content (8.5 and $6.9 \mathrm{~kg} \mathrm{t}^{-1}$ ) and limited neutralizing capacity of existing calcite. The potential risk of environmental contamination in case of these tailings is confirmed also by the acidic $\mathrm{pH}$ values (2.7 and 2.6) of leachate.

The ARD generation in the Cutii and Sartas impoundments is determined by the oxidation of metal sulphides and hydrolysis or/and dissolution of sulphate minerals 
Table 5 Tailings characteristics linked to ARD generation potential

\begin{tabular}{|c|c|c|c|c|c|c|}
\hline Impoundment & $\mathrm{pH}$ of leachate & $\begin{array}{l}S \\
k g t^{-1}\end{array}$ & $\begin{array}{l}\mathrm{NP}^{\mathrm{a}} \\
\mathrm{kg} \mathrm{CaCO}_{3} \mathrm{t}^{-1}\end{array}$ & $\begin{array}{l}\mathrm{APP}^{\mathrm{b}} \\
\mathrm{kg} \mathrm{CaCO}_{3} \mathrm{t}^{-1}\end{array}$ & $\begin{array}{l}\mathrm{NNP}^{\mathrm{c}} \\
\mathrm{kg} \mathrm{CaCO}_{3} \mathrm{t}^{-1}\end{array}$ & ARD generation potential \\
\hline Sartas & 2.7 & 8.5 & 0.0 & 26.6 & -26.6 & certain \\
\hline Cutii & 2.6 & 6.9 & 0.6 & 21.6 & -21.0 & certain \\
\hline Saliste & 2.9 & 0.7 & 0.0 & 2.2 & -2.2 & uncertain \\
\hline Gura Rosiei & 3.5 & 0.8 & 1.25 & 2.3 & -1.1 & uncertain \\
\hline Sesei & 8.2 & 0.5 & 12.0 & 1.6 & 10.4 & uncertain \\
\hline Stefanca & 10.5 & 0.6 & 18.7 & 1.9 & 16.9 & uncertain \\
\hline Brazesti & 8.1 & 1.6 & 102 & 5.0 & 97.0 & no \\
\hline
\end{tabular}

${ }^{\mathrm{a}} \mathrm{NP}$ - neutralization potential expressed as $\mathrm{kg} \mathrm{CaCO}_{3} \mathrm{t}^{-1}$ tailings; ${ }^{\mathrm{b}} \mathrm{APP}$ - acid producing potential expressed in calcite consumed for neutralization ( $\mathrm{kg}$ CaCO $\mathrm{t}^{-1}$ ) at $\mathrm{pH}>6.3 ;{ }^{\mathrm{C}} \mathrm{NNP}$ - net neutralization potential calculated as the difference NP-APP.

especially during rainfalls and infiltration of water in tailings, causing a drop of $\mathrm{pH}$ in the range of $1.5-3$. The pyrite oxidation by atmospheric oxygen takes place according to equation 1 [26,27].

$$
\begin{aligned}
& \mathrm{FeS}_{2}(s)+15 / 4 \mathrm{O}_{2}(a q)+7 / 2 \mathrm{H}_{2} \mathrm{O} \\
& \quad=\mathrm{Fe}(\mathrm{OH})_{3}(s)+\mathrm{SO}_{4}{ }^{2-}(a q)+4 H^{+}(a q)
\end{aligned}
$$

Galena and sphalerite oxidation by aqueous ferric iron (equation 2) generates significantly greater quantities of acid than its oxidation by oxygen (equation 3) [28].

$$
\begin{aligned}
& 2 \mathrm{MeS}(s)+4 \mathrm{Fe}^{3+}(a q)+3 \mathrm{O}_{2}(a q)+2 \mathrm{H}_{2} \mathrm{O} \\
& =2 \mathrm{Me}^{2+}(a q)+4 \mathrm{Fe}^{2+}(a q)+2 \mathrm{SO}_{4}{ }^{2-}(a q) \\
& \quad+4 H^{+}(a q) \\
& \mathrm{MeS}(s)+2 \mathrm{O}_{2}(a q)=\mathrm{Me}^{2+}(a q)+\left(\mathrm{SO}_{4}{ }^{2-}\right)(a q)
\end{aligned}
$$

This process is confirmed by the presence of anglesite $\left(\mathrm{PbSO}_{4}\right)$ identified in traces by XRD analysis. The hydrolysis process suffered by jarosite resulted in post mining oxidation is presented in equation 4 [13,26-28].

$$
\begin{aligned}
\mathrm{KFe}_{3}\left(\mathrm{SO}_{4}\right)_{2}(\mathrm{OH})_{6}(s)= & K^{+}(a q)+3 \mathrm{FeOOH}(s) \\
& +2 \mathrm{SO}_{4}{ }^{2-}(a q) \\
& +3 H^{+}(a q)
\end{aligned}
$$

The dissolution process of most common secondary minerals (iron sulphate and gypsum) should be also considered as acid source [26,27].

Minerals with neutralization potential identified in tailings were calcite, effective at $\mathrm{pH} \geq 5.7$, and aluminosilicates (albite and biotite), reactive at $\mathrm{pH} \leq 3.1$ [29-31]. Following the neutralization process, the aluminosilicate minerals liberate ions of $\mathrm{Al}^{3+}, \mathrm{Fe}^{3+}, \mathrm{Mn}^{2+}$, alkaline, earth-alkaline and ions of hazardous/priority hazardous metals from tailing wastes. The $\mathrm{K}^{+}$and $\mathrm{Fe}^{3+}$ ions released from the biotite dissolution are further involved in the precipitation of jarosite that occurs in oxidized tailings in acidic environments [31,32]. These processes are most likely to occur in the Sartas impoundment, since the mineralogical analysis revealed a high concentration of biotite and jarosite. The source of $\mathrm{Ca}^{2+}$ ions necessary for the formation of gypsum, another secondary mineral associated with ARD generation, is the dissolution of calcite, anorthoclase and feldspar.

Tailings from the Brazesti impoundment does not represent an ARD source as shows the positive NNP determined by a content of $97 \mathrm{~kg} \mathrm{CaCO}_{3} \mathrm{t}^{-1}$ tailings in excess compared with the required stoichiometric amount. The other impoundments were found to be uncertain sources of ARD.

\section{Environmental contamination risk with hazardous/priority hazardous metals and ions}

To highlight whether these tailings pose a contamination risk, the total and leached fraction of hazardous/priority hazardous metals and ions concentrations in leachate were taken into account. In order to illustrate the contamination risk for soil, sediments, surface and groundwater the weight of each contaminant that exceeded the limit values was calculated as the ratio between the found and reference values set by quality standards. Similar approach was used for the grouping of analysed tailings as inert or non-inert. The obtained results are presented in Figure 2.

The potential contamination risk by diffusion of metals in soil and river sediments in the anthropogenic impact area was estimated by comparing the total content of hazardous/priority hazardous metals with threshold/trigger levels for less sensitive soil use and sediment quality guidelines complying with the Romanian regulation $[33,34]$ (Table 6). Threshold level is the concentration above which the contaminant should generally be regarded as undesirable and possible unacceptable and some forms of remedial action may be necessary. Trigger level indicates the contaminant concentration above which it is considered as posing an environmental risk and clean-up is necessary. The comparison allowed to classify tailings as follows: unpolluted (group 1) when the total metal content was below the threshold level; medium polluted (group 2) for contents between 


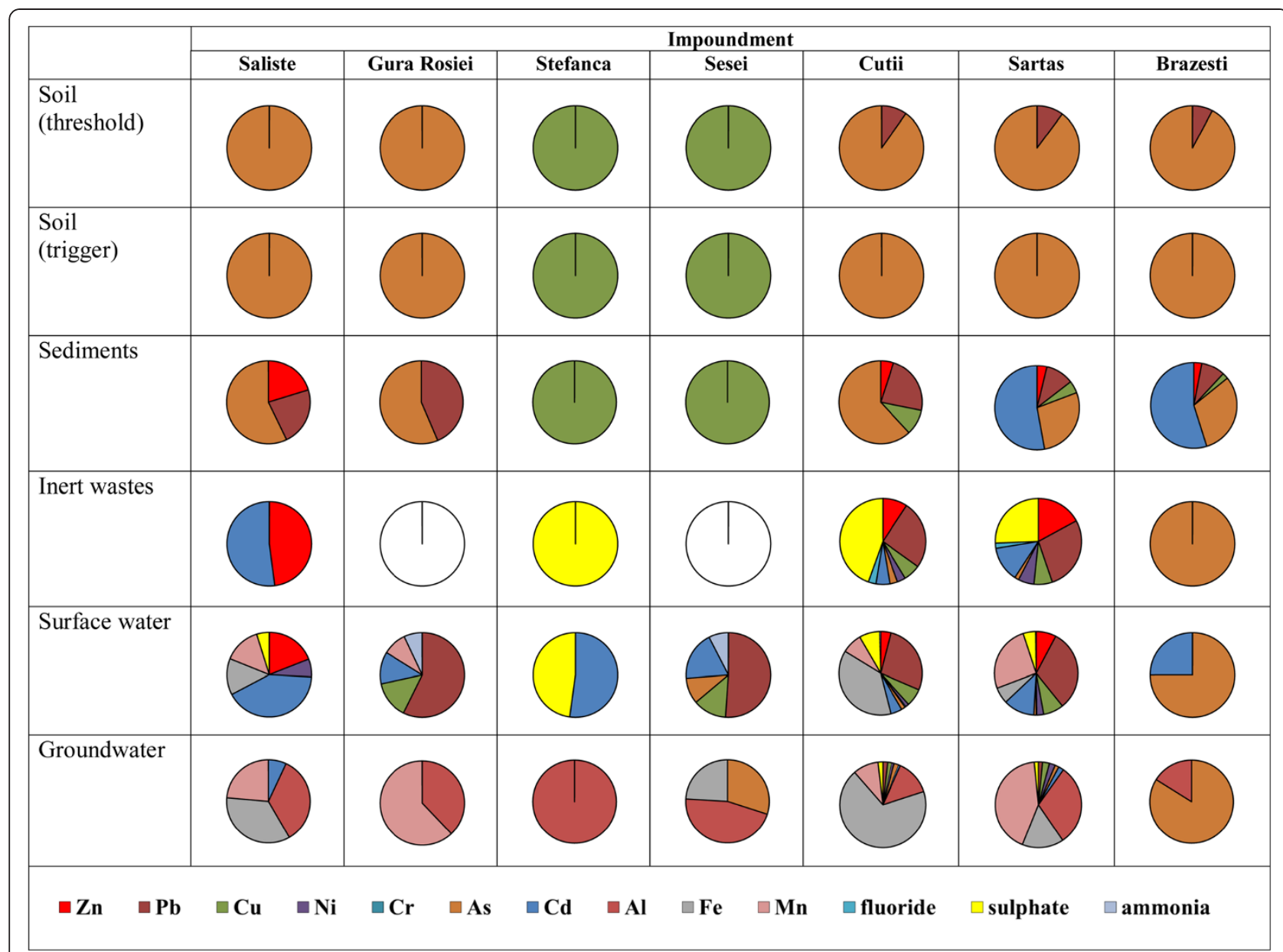

Figure 2 Weight of contaminants that exceed the corresponding limit value for soil, sediment, waste and water. Legend: The weight of each contaminant that exceed the corresponding limit value for soil, sediments, inert wastes, surface and ground waters was calculated as the ratio between the found (Table 3 ) and reference values (Table 6).

threshold and trigger levels and highly polluted (group 3) for values exceeding trigger levels. Based on these considerations tailings from all impoundments were classified as belonging to group 3 of high contamination risk for soil, those of Saliste, Gura Rosiei, Cutii, Sartas and Brazesti because of As, while those of Stefanca and Sesei because of $\mathrm{Cu}$. In terms of $\mathrm{Pb}$, the impoundments Cutii, Sartas and Brazesti were found to correspond to group 2 of medium contamination risk. Tailings were also found to present a high contamination risk for sediment because the total content of hazardous/priority hazardous metals exceeded the sediment quality guidelines. The contamination risk of sediment decreases in the order: Brazesti $\approx \mathrm{Sartas}>\mathrm{Cutii} \quad(\mathrm{Cd}>\mathrm{Pb}>\mathrm{Cu}>\mathrm{Zn})>$ Saliste $>-$ Gura Rosiei $(\mathrm{As}>\mathrm{Pb})>$ Stefanca $\approx \mathrm{Sesei}(\mathrm{Cu})$.

Beside the total content of metals, another useful criterion to assess the potential risk of environmental contamination used in this study was the leaching fraction of metals and ions because it expresses water mobility. The reason is that even low total concentrations of a contaminant can exhibit high leachability and thus a significant risk for environment and vice versa [12]. Comparison of the leachable fraction of metals and ions in tailings at a solid-to-water ratio of 1:10 (Table 3) with the leaching limit values for inert waste [35] (Table 6) shows that the requirements are fulfilled only for the Gura Rosiei and Sesei impoundments, while the other tailings cannot be considered of no contamination risk. The highest exceeding of leaching limit value for inert waste was registered for the tailings of Sartas $(\mathrm{Zn}, \mathrm{Cu}$, $\left.\mathrm{Ni}, \mathrm{F}^{-}, \mathrm{SO}_{4}^{2-}\right)$ and $\mathrm{Cutii}\left(\mathrm{Zn}, \mathrm{Cu}, \mathrm{SO}_{4}^{2-}\right)$ impoundments (Figure 2). In fact, the Acid Base Accounting (ABA) test indicated these tailings as considerable sources of ARD, which explained the high concentration of the previously mentioned elements and anions in leachate. The accepting criteria for inert wastes of some indicatives were also surpassed in the tailings leachates of Saliste $(\mathrm{Zn}, \mathrm{Cd})$, Stefanca $\left(\mathrm{SO}_{4}^{2-}\right)$ and Brazesti (As).

To highlight the possible contamination risk for surface water, content of metals and ions in leachate were 
Table 6 Limit values according to quality guidelines for inert waste, soil, sediment and water

\begin{tabular}{|c|c|c|c|c|c|c|}
\hline \multirow[t]{2}{*}{ Parameter } & \multirow{2}{*}{$\begin{array}{l}\text { Leaching limit } \\
\text { values for inert } \\
\text { waste [35] } \\
\mathrm{mg} \mathrm{kg}^{-1}\end{array}$} & \multicolumn{2}{|c|}{ Soil guidelines for less sensitive use [33] } & \multirow{2}{*}{$\begin{array}{l}\text { Sediment quality } \\
\text { guideline [34] } \\
\mathrm{mg} \mathrm{kg}^{-1}\end{array}$} & \multirow{2}{*}{$\begin{array}{l}\text { Surface water } \\
\text { quality standards }{ }^{\mathrm{a}} \text { [34] } \\
\mathrm{mg} \mathrm{l}^{-1}\end{array}$} & \multirow{2}{*}{$\begin{array}{l}\text { Threshold value } \\
\text { for groundwater [37] } \\
\mathrm{mg} \mathrm{l}^{-1}\end{array}$} \\
\hline & & $\begin{array}{l}\text { Threshold } \\
\mathrm{mg} \mathrm{kg}^{-1}\end{array}$ & $\begin{array}{l}\text { Trigger } \\
\text { mg kg }^{-1}\end{array}$ & & & \\
\hline $\mathrm{Al}$ & - & - & - & - & - & $0.2^{b}$ \\
\hline $\mathrm{Fe}$ & - & - & - & - & $0.3-2$ & $0.2^{b}$ \\
\hline$\overline{\mathrm{Mn}}$ & - & 2000 & 4000 & - & $0.05-1$ & $0.05^{\mathrm{b}}$ \\
\hline $\mathrm{Ba}$ & 20 & 1000 & 2000 & - & - & - \\
\hline $\mathrm{Zn}$ & 4 & 700 & 1500 & 150 & $0.1-1$ & $5^{\mathrm{b}}$ \\
\hline $\mathrm{Pb}$ & 0.5 & 250 & 1000 & 85 & $0.005-0.05$ & $0.01^{\mathrm{b}}$ \\
\hline $\mathrm{Cu}$ & 2 & 250 & 500 & 40 & $0.02-0.1$ & $0.1^{b}$ \\
\hline $\mathrm{Ni}$ & 0.4 & 200 & 500 & 35 & $0.01-0.1$ & $0.02^{b}$ \\
\hline $\mathrm{Cr}$ & 0.5 & 300 & 600 & 100 & $0.025-0.25$ & $0.05^{b}$ \\
\hline As & 0.5 & 25 & 50 & 29 & $0.01-0.1$ & $0.01^{b}$ \\
\hline $\mathrm{Cd}$ & 0.04 & 5 & 10 & 0.8 & $0.0005-0.005$ & $0.005^{b}$ \\
\hline $\mathrm{Co}$ & - & 100 & 250 & - & - & - \\
\hline V & - & 20 & 40 & - & - & - \\
\hline $\mathrm{Ag}$ & - & 200 & 400 & - & - & - \\
\hline $\mathrm{F}-$ & 10 & - & - & - & - & - \\
\hline $\mathrm{Cl}^{-}$ & 800 & - & - & - & $25-300$ & 250 \\
\hline $\mathrm{SO}_{4}^{2-}$ & 1000 & - & - & - & $60-300$ & 310 \\
\hline $\mathrm{NO}_{3}^{+}$ & - & - & - & - & $1-11.2$ & $50^{b}$ \\
\hline $\mathrm{NH}_{4}^{+}$ & - & - & - & - & $0.4-3.2$ & 0.7 \\
\hline
\end{tabular}

ainimum value-very good ecological status; maximum value-bad ecological status;

${ }^{\mathrm{b}} \mathrm{MAC}$ (Maximum Allowable Concentrations) for drinking water [40].

compared with limit values in accordance with [34]. The contamination risk for groundwater was also investigated. The European Community has prepared Guidelines for the establishment of own threshold values of pollutants in groundwater by Member States [36] considering the lithological and hydrogeological characteristics of the groundwater bodies including information on background levels and water balance. According to [37], in the case of the Aries basin there were established threshold values for groundwater only in terms of $\mathrm{Cl}^{-}, \mathrm{SO}_{4}^{2-}$ and $\mathrm{NH}_{4}^{+}$. Based on the 2000/60/EC Directive [38] and a case study [39], the threshold values for metals in groundwater in Romania were establish to be the Maximum Allowable Concentrations (MAC) in drinking water [40]. The exceeding of the limit values for surface and groundwater by the considered contaminants in leachate reveals significant differences in risk contamination from one impoundment to another. According to quality standards for surface water, leachates generated by tailings from the Sartas and Cutii impoundments were found to have bad ecological status $(\mathrm{V})$ and thus the highest contamination risk because of $\mathrm{Fe}, \mathrm{Cu}, \mathrm{Zn}, \mathrm{Cd}, \mathrm{Ni}$ and $\mathrm{SO}_{4}^{2-}$ concentration. Poor status (IV) was attributed to leachate generated by tailings of the Saliste (Fe, $\mathrm{Cu}, \mathrm{Cd}$ ) and Brazesti (As) impoundments, and moderate ecological status (III) to leachate from Sesei $(\mathrm{Cu}, \mathrm{Cd})$ and Gura Rosiei and Stefanca $(\mathrm{Cd})$.
The level of sulphate in leachate is mainly controlled by the solubilisation of gypsum, jarosite and ferric sulphate, while that of trace metals by the desorption from aluminosilicates and S-containing acid waste rocks. To sum up, tailings from impoundments represent a contamination risk for the Aries river basin in wet seasons according to the classification of the corresponding leachates. The groundwater contamination risk by $\mathrm{Al}, \mathrm{As}, \mathrm{Cd}, \mathrm{Cu}, \mathrm{Fe}$, $\mathrm{Mn}, \mathrm{Ni}, \mathrm{Pb}$ and $\mathrm{SO}_{4}^{2-}$ could come mainly from the Cutii and Sartas impoundments. Contamination by As could also originate from tailings stored in the Sesei and Brazesti impoundments, while by $\mathrm{Al}, \mathrm{Cd}, \mathrm{Fe}$ and $\mathrm{Mn}$ from Saliste.

\section{Principal component analysis and agglomerative hierarchical clustering}

Multivariate statistical analysis for evaluation and interpretation of the data allows discriminating between natural and anthropogenic origin of contaminants and pollution levels respectively, within a contaminated site [41-43]. R-mode PCA was applied to total content of metals and sulphur in tailings and leached fractions of metals and ions. According to the Kaiser criterion, only the PC's with eigenvalue higher than 1.0 was retained and subjected to varimax rotation. Factor loadings used to determine the relative importance of a variable as 
compared to other variables in a PC were classified as 'strong,' 'moderate', and 'weak' corresponding to absolute loading value of $>0.75,0.50-0.75$, and $0.30-0.50$ respectively $[44,45]$.

The varimax rotated loadings of 4 PC's with eigenvalues $>1$ (95\% of the system variability) considering as variables the total element contents and ABA test parameters are presented in Table 7. Data in Table 7 show that hazardous/priority hazardous metals exhibit different association to waste rocks. The first factor (PC1) accounting for $47 \%$ of the total variance was attributed to alkaline silicate rocks (aluminosilicates and ferrosilicates) of low neutralization potential and host for $\mathrm{Cu}$, $\mathrm{Co}, \mathrm{V}$ and $\mathrm{Ti}$ mineralization. The lack of correlation between $\mathrm{S}$ and $\mathrm{Ba}$ in this $\mathrm{PC}$ shows that $\mathrm{Ba}$ is not present as barite $\left(\mathrm{BaSO}_{4}\right)$ of anthropogenic origin. In turn, the positive correlation with biogenic elements (K, Na) suggests the biogenic origin of $\mathrm{Ba}$ that can be retained by adsorption on aluminosilicates or iron oxides following

Table 7 Loadings of the 4 PC's considering as variables the total metals, S and ABA parameters

\begin{tabular}{|c|c|c|c|c|}
\hline Parameter & PC1 & PC2 & PC3 & PC4 \\
\hline $\mathrm{Al}$ & $0.868^{* *}$ & -0.248 & -0.082 & 0.108 \\
\hline $\mathrm{Fe}$ & $0.551^{*}$ & $0.618^{*}$ & -0.048 & 0.096 \\
\hline $\mathrm{Ca}$ & 0.000 & $0.904^{* *}$ & 0.191 & -0.015 \\
\hline $\mathrm{K}$ & $0.797^{* *}$ & -0.002 & -0.218 & 0.152 \\
\hline $\mathrm{Mg}$ & $0.862^{* *}$ & -0.199 & 0.207 & 0.033 \\
\hline $\mathrm{Na}$ & $0.869^{* *}$ & -0.208 & -0.119 & -0.027 \\
\hline $\mathrm{Mn}$ & $0.836^{* *}$ & 0.009 & 0.329 & 0.182 \\
\hline $\mathrm{Ba}$ & $0.662^{*}$ & -0.154 & -0.196 & $0.518^{*}$ \\
\hline $\mathrm{Zn}$ & -0.134 & $0.743^{*}$ & 0.176 & 0.495 \\
\hline $\mathrm{Pb}$ & -0.273 & $0.872^{* *}$ & 0.100 & 0.101 \\
\hline $\mathrm{Cu}$ & $0.862^{* *}$ & -0.239 & -0.095 & 0.001 \\
\hline $\mathrm{Ni}$ & 0.060 & $0.613^{*}$ & -0.047 & $0.640^{*}$ \\
\hline $\mathrm{Cr}$ & 0.220 & $0.575^{*}$ & -0.127 & $0.659^{*}$ \\
\hline As & -0.247 & $0.843^{* *}$ & 0.273 & 0.095 \\
\hline $\mathrm{Cd}$ & -0.124 & $0.612^{*}$ & 0.421 & $0.533^{*}$ \\
\hline $\mathrm{CO}$ & $0.855^{* *}$ & -0.169 & 0.126 & 0.093 \\
\hline $\mathrm{Sr}$ & $0.820^{* *}$ & 0.339 & 0.210 & -0.043 \\
\hline $\mathrm{Ti}$ & $0.856^{* *}$ & -0.337 & -0.088 & 0.005 \\
\hline$\underline{V}$ & $0.739^{*}$ & -0.428 & -0.092 & 0.044 \\
\hline W & -0.220 & $0.858^{* *}$ & 0.245 & 0.015 \\
\hline $\mathrm{Ag}$ & $-0.850^{* *}$ & -0.163 & -0.292 & 0.145 \\
\hline $\mathrm{Au}$ & $-0.811^{* *}$ & 0.035 & -0.218 & 0.161 \\
\hline NNP & 0.122 & 0.002 & $0.915^{* *}$ & -0.023 \\
\hline $\mathrm{S}$ & -0.149 & $0.799^{* *}$ & -0.432 & 0.087 \\
\hline NP & 0.093 & 0.232 & $0.890^{* *}$ & 0.000 \\
\hline APP & -0.145 & $0.800^{* *}$ & -0.432 & 0.089 \\
\hline Variability (\%) & 47 & 31 & 12 & 5 \\
\hline
\end{tabular}

**strong influence on the latent factor $(>0.75)$; ${ }^{*}$ moderate influence on the latent factor $(0.50-0.75)$. diagenetic processes. Barium has the ability to replace biogenic elements like $\mathrm{K}$ in sedimentary rocks due to their similar ionic radius [46]. The negative loading factors of $\mathrm{Au}$ and $\mathrm{Ag}$ in this $\mathrm{PC}$ indicate that precious metals are not associated with silicates and exhibit different mineralization type. Low loadings of $\mathrm{Au}$ and $\mathrm{Ag}$ in the other three PCs show that precious metals have no significant influence in describing variability of tailings composition.

The second principal component (PC2) with a contribution of $31 \%$, attesting association of $\mathrm{S}$ with $\mathrm{Fe}$, was attributed to $\mathrm{S}$-containing minerals (sulphides and sulphates), which host $\mathrm{Zn}, \mathrm{Pb}, \mathrm{Cd}$, As and W. These minerals constitute the main contamination source of soil and water in surrounding areas with hazardous (As, $\mathrm{Zn}$ ) and priority hazardous $(\mathrm{Cd}, \mathrm{Pb})$ metals resulted from sulphide oxidation and dissolution of soluble sulphates.

PC3 (12\%) was attributed to carbonate minerals of high ARD neutralization capacity. The positive correlation between NP and NNP indicates sufficient neutralization potential of tailings with two exceptions. It was previously shown that the tailings impoundments of Cutii and Sartas are certain sources of ARD and thereby $\mathrm{Cd}$ and $\mathrm{Mn}$ can be released from carbonate host rocks on which these elements are preferentially retained. However, the low factor loadings of $\mathrm{Cd}$ and $\mathrm{Zn}, \mathrm{Pb}$, As in PC3 compared to PC2 show that carbonates are not the main source of hazardous metals in water.

Chromium and $\mathrm{Ni}$ with low influence $(5 \%)$ on the variability of elemental composition of tailings are included in PC4 ascribed to traces of biogenic elements. The correlation between $\mathrm{Cr}, \mathrm{Ni}$ and $\mathrm{Ba}$, although was moderate, it suggests the biogenic origin of these two metals, as a result of their adsorption in clay minerals by diagenetic processes [46].

PCA analysis on data obtained from the leaching study shows that $96 \%$ of variability is shared among four PC's (Table 8). The first component (PC1) accounting for $61 \%$ variability was associated to priority hazardous $(\mathrm{Cd}$, $\mathrm{Ni}$ ) and hazardous ( $\mathrm{Cu}, \mathrm{Co}, \mathrm{Cr}, \mathrm{Zn})$ metals as well as $\mathrm{Mn}$ and anions $\left(\mathrm{F}^{-}, \mathrm{SO}_{4}^{2-}\right)$ retained on $\mathrm{Al}$ and $\mathrm{Mg}$ minerals leached in water. In accordance with its factor loading, sulphate has a moderate influence on the metals mobility in water. PC2 (18\%) was attributed to biogenic elements $\left(\mathrm{K}, \mathrm{Na}, \mathrm{Cl}^{-}, \mathrm{NO}_{3}^{-}\right.$) with no contamination risk for water. The third component (PC3) of $11 \%$ variability was assigned to priority hazardous $(\mathrm{Pb})$ and hazardous metals $(\mathrm{Cr})$ as well as ions $\left(\mathrm{F}^{-}, \mathrm{SO}_{4}^{2-}, \mathrm{NH}_{4}^{+}\right)$leached from oxidized $\mathrm{S}$-containing minerals (Fe and $\mathrm{Ca}$ sulphates). The last component (PC4) explaining 6\% of variability was associated to biogenic matter. Although moderate, the correlation between dissolved organic carbon (DOC) and water leachable $\mathrm{Ba}$ fraction suggests the biogenic origin of this element in tailings. This finding is in 
Table 8 Loadings of the 4 PC's considering as variables the leached metals and ions concentration

\begin{tabular}{|c|c|c|c|c|}
\hline Parameter & PC1 & PC2 & PC3 & PC4 \\
\hline$\overline{\mathrm{Al}}$ & $0.864^{* *}$ & -0.017 & 0.330 & 0.019 \\
\hline $\mathrm{Fe}$ & 0.070 & -0.143 & $0.909^{* *}$ & 0.065 \\
\hline $\mathrm{Ca}$ & 0.278 & -0.047 & $0.875^{* *}$ & 0.092 \\
\hline K & -0.105 & $0.873^{* *}$ & -0.193 & 0.211 \\
\hline $\mathrm{Mg}$ & $0.903^{* *}$ & -0.109 & 0.061 & 0.087 \\
\hline $\mathrm{Na}$ & -0.097 & $0.914^{* *}$ & -0.053 & 0.078 \\
\hline$\overline{M n}$ & $0.905^{* *}$ & -0.059 & 0.181 & -0.001 \\
\hline $\mathrm{Ba}$ & 0.083 & $0.682^{*}$ & -0.031 & $0.513^{*}$ \\
\hline $\mathrm{Zn}$ & $0.874^{* * *}$ & -0.095 & 0.287 & -0.015 \\
\hline $\mathrm{Pb}$ & $0.589^{*}$ & -0.178 & $0.685^{*}$ & 0.077 \\
\hline $\mathrm{Cu}$ & $0.792^{* *}$ & -0.109 & 0.465 & 0.032 \\
\hline $\mathrm{Ni}$ & $0.882^{* *}$ & -0.083 & 0.267 & -0.005 \\
\hline$\overline{\mathrm{Cr}}$ & $0.566^{*}$ & -0.280 & $0.612^{*}$ & -0.011 \\
\hline$\overline{\text { As }}$ & 0.370 & -0.362 & 0.400 & 0.413 \\
\hline $\mathrm{Cd}$ & $0.901^{* *}$ & -0.085 & 0.188 & -0.027 \\
\hline $\mathrm{Co}$ & $0.900^{* *}$ & -0.064 & 0.202 & -0.004 \\
\hline $\mathrm{Sr}$ & 0.322 & 0.277 & $0.802^{* *}$ & 0.153 \\
\hline$\overline{\mathrm{Ti}}$ & $0.584^{*}$ & -0.130 & $0.696^{*}$ & 0.104 \\
\hline $\mathrm{pH}$ & -0.319 & $0.543^{*}$ & -0.411 & $0.516^{*}$ \\
\hline $\mathrm{EC}$ & $0.543^{*}$ & -0.048 & $0.745^{*}$ & 0.045 \\
\hline$\overline{D O C}$ & 0.073 & 0.069 & 0.398 & $0.791^{* *}$ \\
\hline $\mathrm{F}^{-}$ & $0.653^{*}$ & -0.027 & $0.649^{*}$ & 0.082 \\
\hline$\overline{\mathrm{Cl}^{-}}$ & -0.008 & $0.734^{*}$ & 0.459 & -0.170 \\
\hline$\overline{\mathrm{NO}_{3}^{-}}$ & -0.189 & $0.852^{* *}$ & -0.120 & -0.227 \\
\hline$\overline{\mathrm{SO}_{4}^{2-}}$ & $0.579^{*}$ & -0.088 & $0.715^{*}$ & 0.055 \\
\hline$\overline{\mathrm{NH}_{4}^{+}}$ & 0.207 & -0.152 & $0.664^{*}$ & -0.290 \\
\hline Variability (\%) & 61 & 18 & 11 & 6 \\
\hline
\end{tabular}

**strong influence on the latent factor $(>0.75) ; *$ moderate influence on the latent factor $(0.50-0.75)$.

accordance with the literature data regarding the effect of organic matter on Ba availability [47,48]. Although in the environment As has a high affinity for the organic matter, in the studied tailings this component has a low influence on the mobilization of As and other hazardous/priority hazardous metals by water [49]. This behaviour is explained by the relatively low content of organic matter $\left(0.5-2.3 \mathrm{~kg} \mathrm{t}^{-1}\right)$ in the studied tailings. Also, increasing $\mathrm{pH}$ favoured especially the mobilization of biogenic elements linked to organic matter as shown by the positive associations in PC2 and PC4.

The $\mathrm{AHC}$ on element concentrations in aqua regia extracts of tailings and neutralization parameters resulted from the ABA test considering tailings impoundments as objects is presented in Figure 3. The grouping of tailings in 3 clusters is consistent with the contamination degree of the stored waste. Cluster $\mathrm{C} 1$ groups the tailings of Brazesti, Sartas and Cutii impoundments

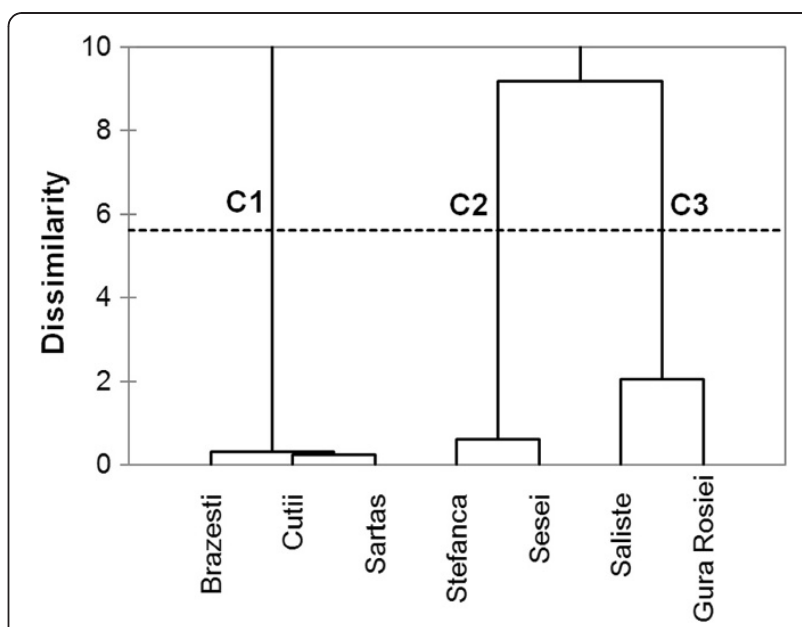

Figure 3 Dendrogram showing the clustering of tailings based on elemental composition and ABA parameters.

exhibiting the highest contamination with $\mathrm{As}, \mathrm{Pb}$ and $\mathrm{Cd}$, while the other two clusters include tailings with lower contamination and thus lower environmental risk, namely Sesei and Stefanca (C2) and Gura Rosiei and Saliste (C3). The grouping of these four impoundments in two subclusters is due to the difference in respect with the main contaminants, namely $\mathrm{Cu}$ (Sesei and Stefanca) and As and Cd (Gura Rosiei, Saliste), respectively.

The dendrogram produced by clustering tailings considering metals and ions concentrations, $\mathrm{pH}$ and electrical conductivity in leachate is presented in Figure 4. Tailings impoundments are grouped in three clusters according to their ARD generation potential. Thus cluster $\mathrm{C} 1$ includes the tailings of Cutii and Sartas impoundments not complying with inert waste criteria. Clusters C2 and C3 group tailings of lower

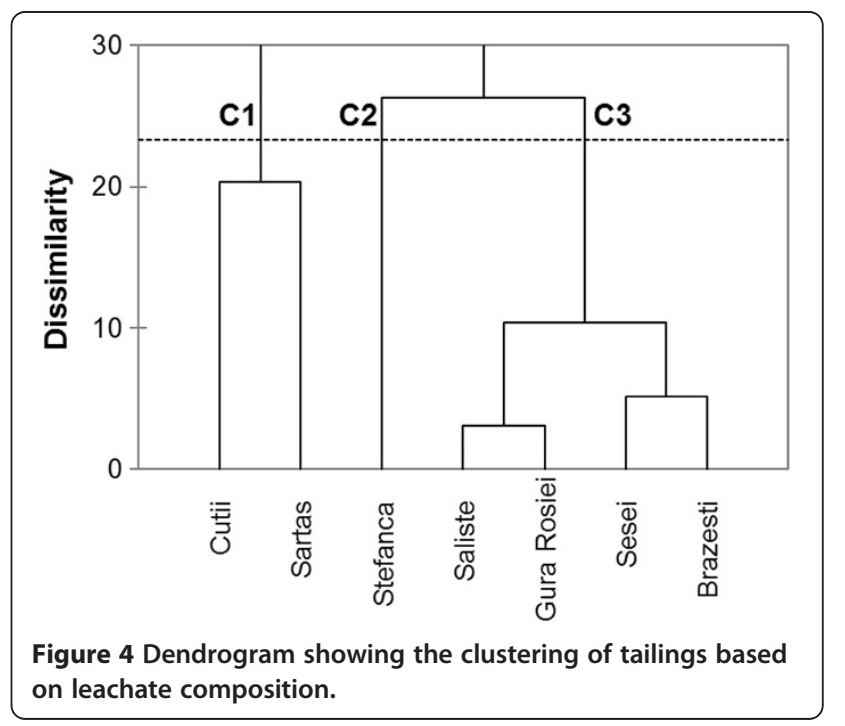


contamination risk for water and classified as uncertain or low ARD generation potential.

\section{Conclusions}

Tailings from mineral processing of $\mathrm{Cu}$ porphyry deposits and stored in seven impoundments in the Aries basin, Apuseni Mountains, Romania, were characterized by mineralogical and elemental composition, potential of ARD generation and leaching test of hazardous/priority hazardous metals and ions. The main contributions of our study are:

i. Classification of tailings from this area based on the potential contamination risk for soil, sediments, surface and ground-waters according to reference quality guidelines

ii. Selection of representative hazardous/priority hazardous metals for the studied impoundments, that allowed to classify the tailings by contamination indices and to highlight the differences between the impoundments related to contaminants influence on the environmental quality

iii. Interpretation of results using multivariate statistics allowed to distinguish between the natural and anthropogenic origin of metals and their grouping in 4 principal components that describe the tailings elemental composition and water leachable fraction of contaminants

iv. Grouping of the tailings impoundments by AHC considering their contamination and ARD generation potential.

Results have indicated that tailings exhibit very high contamination degree for soil, especially with $\mathrm{As}, \mathrm{Pb}, \mathrm{Cu}$ and $\mathrm{Cd}$. Based on the total contents of these elements, three impoundments were found to represent high and medium contamination risk with $\mathrm{As}, \mathrm{Pb}$ and $\mathrm{Cd}$, whereas two impoundments show high contamination risk with $\mathrm{As}$ and other two with $\mathrm{Cu}$. The tailings impoundments evidenced a high potential contamination risk with $\mathrm{As}, \mathrm{Pb}, \mathrm{Cu}$ and $\mathrm{Cd}$ of river sediment. Two tailings impoundments (Cutii and Sartas) were classified as hazardous because of the leached fraction of metals and ions and ARD generation potential. Groundwater contamination with $\mathrm{Fe}, \mathrm{Al}$ and $\mathrm{Mn}$ is also possible.

Principal component analysis has shown that the variability of total element contents and that of leachable hazardous/priority hazardous metals and ions are controlled mainly by alkaline silicates containing $\mathrm{Al}$ and $\mathrm{Mg}$, and acidic minerals with $\mathrm{S}, \mathrm{Fe}$ and $\mathrm{Ca}$. Organic matter had low influence on the element leachability excepting some biogenic elements such as $\mathrm{Ba}$. Increasing $\mathrm{pH}$ favours only the mobilization of biogenic elements of no contamination risk. Although, PCA offers important information concerning the influence of different parameters on the hazardous/priority hazardous metals behaviour in tailings, has also limitations and disadvantages. The main limitations are that results interpretation in not based on the original data but on a new set of independent variables (PCs) and the resulting PCs have limited comparability among different studies. The reduction of data set is based on linear transformations and the maximisation of PCs is made in the detriment of others with less variability. In addition, it requires large dataset but is difficult to deal with missing data or outliers.

Although some measures have been taken to green the tailings impoundments, they continue to act as potential contamination sources of the environment and are vulnerable by rainwater infiltration to mobilization of hazardous/priority hazardous metals and ions from secondary minerals. In our opinion, a monitoring program of these tailings impoundments would be helpful to continue, even after greening completion.

\section{Methods \\ Collection and preparation of samples and analytical methods}

Five sub-samples from each of the seven tailings impoundments were randomly collected in July 2012 from $25 \mathrm{~cm}$ depth using a polypropylene shovel. For each impoundment the sub-samples were mixed to obtain a composite sample that was subjected to analysis. The bulk mineralogical composition was determined by powder X-ray diffraction (XRD) using the highresolution Bruker D8 Advance diffractometer (BrukerAXS, Karlsruhe, Germany) at $\mathrm{Cu} \mathrm{K}_{\alpha}$ radiation after grinding and homogenizing of samples to $<63 \mu \mathrm{m}$. Samples were analysed for total metal concentrations by inductively coupled plasma atomic emission spectrometry (ICP-AES) and inductively coupled plasma mass spectrometry (ICP-MS) after mineralization. An amount of $1 \mathrm{~g}$ dried sample $\left(105 \pm 5^{\circ} \mathrm{C}\right)$ was treated with $28 \mathrm{ml}$ aqua regia according to SR ISO 11466:1995. The filtrate was diluted to $100 \mathrm{ml}$ with ultrapure water and the contents of $\mathrm{Ca}, \mathrm{Mg}, \mathrm{Na}, \mathrm{K}, \mathrm{Al}, \mathrm{Fe}, \mathrm{Cu}, \mathrm{Pb}, \mathrm{Zn}, \mathrm{Mn}, \mathrm{Ba}$ and $\mathrm{Sr}$ were determined by ICP-AES (OPTIMA 5300 DV, Perkin Elmer, Norwalk, USA), while those of $\mathrm{Cd}, \mathrm{As}, \mathrm{Ti}, \mathrm{Ni}, \mathrm{Cr}$, $\mathrm{Co}, \mathrm{Au}, \mathrm{Ag}, \mathrm{V}, \mathrm{W}$ by ICP-MS (ELAN DRC II, SCIEX, Perkin Elmer, Toronto, Canada). Arsenic was determined as ${ }^{75} \mathrm{As}^{16} \mathrm{O}^{+}$polyatomic ion using the dynamic reaction cell technology at $0.8 \mathrm{ml} \mathrm{min}^{-1}$ oxygen and $\mathrm{RPq}=0.45$. The ICP-AES technique was previously validated for the analysis of granular waste with metal recovery in the range $91-109 \%$ and $0.8-4.6 \%$ repeatability [50]. Sulphur content in tailings samples was determined by $\mathrm{X}$ ray fluorescence using the spectrometer $\alpha 6500$ (INNOV-X, Woburn, MA, US). 
To characterize the water mobility of hazardous/priority hazardous metals and ions, tailings were subjected to leaching at a solid-to-water ratio of 1:10 as described in SR EN 12457-2:2003. An amount of wet granular sample with particle size below $4 \mathrm{~mm}$ corresponding to $90 \mathrm{~g}$ dry mass was leached for $24 \pm 0.5 \mathrm{~h}$ at room temperature $\left(20 \pm 5{ }^{\circ} \mathrm{C}\right)$ using the REAX 20 overhead shaker (Heildolph, Schwabach, Germany). The leachate was analysed for metal contents by ICP-MS and main anions $\left(\mathrm{Cl}^{-}, \mathrm{NO}_{3}^{-}, \mathrm{F}^{-}, \mathrm{SO}_{4}^{2-}\right)$ respectively, by ion-liquid chromatography according to ISO 10304-1:2007 using the 761 Compact IC (Metrohm, Herisau, Switzerland).

Ammonium ions in leachate were determined as indophenol blue complex according to SR ISO 71501:2001 using the spectrophotometer Lambda 25 (Perkin Elmer, Beaconsfield, UK). The electric conductivity and $\mathrm{pH}$ of leachate were measured with the 350i multiparameter (WTW, Wilheim, Germany), while the DOC content was assessed according to SR EN 1484:2006 using the Multi N/C 2100S Analyser (Analytik Jena, Jena, Germany).

The ABA test was conducted to evaluate the ARD generation capacity of tailings estimated by NNP. According to Sobeck et al. [51] it is calculated as the difference between Neutralization Potential (NP) and Acid Producing Potential (APP) assuming that sulphur is present only in the form of pyrite, while carbonate as calcite $\left(\mathrm{CaCO}_{3}\right)$. The NP expressed as the content of $\mathrm{CaCO}_{3}\left(\mathrm{~kg} \mathrm{t}^{-1}\right)$ resulted from the titration with $\mathrm{NaOH}$ solution, of the acid excess used for sample mineralization. The APP level at $\mathrm{pH}<6.3$ was estimated considering that each $\mathrm{S}$ percent requires for neutralization $31.25 \mathrm{~kg} \mathrm{CaCO}_{3} \mathrm{t}^{-1}$ tailings. The material is considered as ARD generating when the $\mathrm{NNP}$ value is lower than $-20 \mathrm{~kg} \mathrm{CaCO}_{3} \mathrm{t}^{-1}$, while a value higher than $+20 \mathrm{~kg} \mathrm{CaCO}_{3} \mathrm{t}^{-1}$ indicates that the material is non-ARD generating. For NNP values between -20 and $+20 \mathrm{~kg} \mathrm{CaCO} \mathrm{t}^{-1}$ the prediction about the ARD generation is uncertain $[52,53]$.

\section{Statistical analysis}

The XLStat Microsoft Excel plug-in (Addinsoft) was used for the statistical processing of the data. Principal Component Analysis with varimax rotation was used to interpret the structure of the main dataset. Agglomerative Hierarchical Clustering using the Ward's linkage method and Euclidian distances as a measure of similarity was used to group the determined parameters into classes.

\section{Competing interests}

The authors declare that they have no competing interests.

\section{Authors' contributions}

EL conceived the study, collected the samples, performed S and DOC determinations, leaching and ABA tests, statistical analysis and helped to manuscript preparation. TF interpreted the results and coordinated the manuscript writing. MP participated to the interpretation of the results and to the manuscript preparation. $C T$ determined the elemental composition of samples and participated to data analysis. GB determined the mineralogical composition of samples by XRD analysis and data interpretation. All authors read and approved the final manuscript.

\section{Acknowledgements}

This work was supported by a grant of the Romanian National Authority for Scientific Research, CNCS - UEFISCDI, project number PN-II-RU-PD-2011-3-0056.

\section{Author details}

${ }^{1}$ INCDO-INOE 2000, Research Institute for Analytical Instrumentation, 67 Donath, 400293, Cluj-Napoca, Romania. ${ }^{2}$ Faculty of Chemistry and Chemical Engineering, Babes-Bolyai University, 11 Arany Janos, 400028, Cluj-Napoca, Romania. ${ }^{3}$ National Institute for Research and Development of Isotopic and Molecular Technologies, 65-103 Donath, 400293, Cluj-Napoca, Romania.

Received: 30 October 2012 Accepted: 8 January 2013

Published: 14 January 2013

\section{References}

1. Dold B: Sustainability in metal mining: from exploration, over processing to mine waste management. Rev Environ Sci Biotechnol 2008, 7:275-285.

2. Moncur MC, Ptacek CJ, Blowes DW, Jambor JL: Release, transport and attenuation of metals from an old tailings impoundment. App/ Geochem 2005, 20:639-659.

3. Sima M, Dold B, Frei L, Senila M, Balteanu D, Zobrist J: Sulfide oxidation and acid mine drainage formation within two active tailings impoundments in the Golden Quadrangle of the Apuseni Mountains, Romania. J Hazard Mater 2011, 189:624-639.

4. Gilchrist S, Gates A, Szabo Z, Lamothe PJ: Impact of AMD on water quality in critical watershed in the Hudson River drainage basin: Phillips Mine, Hudson Highlands, New York. Environ Geol 2009, 57:397-409.

5. Favas PJC, Pratas J, Gomes MEP, Cala V: Selective chemical extraction of heavy metals in tailings and soils contaminated by mining activity: Environmental implications. J Geochem Explor 2011, 111:160-171.

6. Luis AT, Teixeira P, Almeida SFP, Ector L, Matos JX, Ferreira da Silva EA: Impact of acid mine drainage (AMD) on water quality, stream sediments and periphytic diatom communities in the surrounding streams of Aljustrel mining area (Portugal). Water Air Soil Pollut 2009, 200:147-167.

7. Garcia C, Ballester A, Gonzales F, Blazquez ML: Pyrite behaviour in a tailings pond. Hydrometalurgy 2005, 76:25-36.

8. Macklin M, Brewer P, Balteanu D, Coulthard T, Driga B, Howard A, Zaharia S: The long term fate and environmental significance of contaminant metals released by the January and March 2000 mining tailings dam failures in Maramures County, upper Tisa basin, Romania. App/ Geochem 2003, 18:241-257.

9. Cordos E, Rautiu R, Roman C, Ponta M, Frentiu T, Sarkany A, Fodorpataky A, Macalik L, McCormick K, Weiss D: Characterization of the rivers systems in the mining and industrial area of Baia Mare, Romania. European J Min Process 2003, 3:324-335.

10. Johnson DB, Hallberg KB: Acid mine drainage remediation options: a review. Sci Total Environ 2005, 338:3-14.

11. Alvarez-Valero AM, Perez-Lopez R, Matos J, Capitan MA, Nieto JM, Saez R, Delgado J, Caraballo M: Potential environmental impact at Sao Domingos mining district (Iberian Pyrite Belt, SW Iberian Peninsula): evidence from a chemical and mineralogical characterization. Environ Geol 2008, 55:1797-1809.

12. Rodriguez L, Ruiz E, Alonso-Azcarate J, Rincon J: Heavy metal distribution and chemical speciation in tailings and soils around a $\mathrm{Pb}-\mathrm{Zn}$ mine in Spain. J Environ Manag 2009, 90:1106-1116.

13. Kossoff D, Hudson-Edwards KA, Dubbin WE, Alfredsson M: Major and trace metal mobility during weathering of mine tailings: implications for floodplain soils. App/ Geochem 2012, 27:562-576.

14. Romero FM, Prol-Ledesma RM, Canet C, Alvares LN, Perez-Vazquez R: Acid drainage at the inactive Santa Lucia mine, western Cuba: Natural attenuation of arsenic, barium and lead, and geochemical bahavior of rare earth elements. Appl Geochem 2010, 25:716-727.

15. Giuliano V, Pagnanelli F, Bornoroni L, Toro L, Abbruzzese C: Toxic elements at a disused mine district: Particle size distribution and total concentration in stream sediments and mine tailings. $J$ Hazard Mater 2007, 148:409-418. 
16. Ohlander B, Chatwin T, Alakangas L: Management of sulphide-bearing waste, a challenge for the mining industry. Minerals 2012, 2:1-10.

17. Governmental Decision No. $351 / 2005$ on the approval of the Programme of gradual removal of emissions and losses of dangerous substances. Official Gazette 2005, Part I, no. 428/20.05.2005 [In Romanian].

18. Hodson ME: Heavy metals-geochemical bogey men? Environ Pollut 2004, 129:341-343.

19. Hakanson L: Ecological risk index for aquatic pollution control. A sedimentological approach. Water Res 1980, 14:975-1001.

20. Buza M, Dimen L, Pop G, Turnock D: Environmental protection in the Apuseni Mountains: The role of Environmental Non-Governmental Organisations (ENGOs). GeoJournal 2001, 55:631-653.

21. Milu V, Leroy $J$, Peiffert $C$ : Water contamination downstream from a copper mine in the Apuseni Mountains, Romania. Environ Geol 2002, 42:773-782.

22. Friedel MJ, Tindall JA, Sardan D, Fey DL, Poputa GL: Reconnaissance study of water quality in the mining-affected Aries River basin, Romania. U.S. Geological Survey. Open-File Report 2008, 1-40. http://pubs.usgs.gov/of/ 2008/1176/pdf/OF08-1176_508.pdf.

23. Sinex SA, Helz GR: Regional geochemistry of trace elements in Chesapeake Bay. Environ Geol 1981, 3:315-323.

24. Muller G: Schwermetalle in den sedimenten des Rheins-Veränderungen seit. Umschau 1979, 79:778-783.

25. Taylor SR, McLennan SM: The geochemical evolution of the continental crust. Rev Geophys 1995, 33:241-265.

26. Lapakko K: Metal mine rock and waste characterization tools: an overview, Mining, Minerals and Sustainable Development, Report No. 67. Acid Drainage Technology Initiative 2002, http://pubs.iied.org/pdfs/G00559.pdf.

27. Dold B: Basic concepts in environmental geochemistry of sulphide minewaste management. In Waste Management. Chapter 10. Edited by Kumar S. InTech Open Access Publications; 2010:173. http://www.intechopen.com/ books/show/title/waste-management.

28. Blowes DW, Ptacek CJ, Jambor JL, Weisener CG: The geochemistry of acid mine drainage. In Treatise on Geochemistry, Volume 9. Edited by Lollar BS. Oxford: Elsevier-Pergamon; 2003.

29. Sverdrup HU: The kinetics of base cation release due to chemical weathering. Lund: Lund University Press; 1990.

30. Kwong YTJ: Prediction and prevention of acid rock drainage from a geological and mineralogical perspective. MEND Project 1993, 1.32.1; 47 http://www.mend-nedem.org/reports/files/1.32.1.pdf.

31. Gunsinger MR, Ptacek CJ, Blowes DW, Jambor JL, Moncur MC: Mechanisms controlling acid neutralization and metal mobility within a Ni-rich tailings impoundment. App/ Geochem 2006, 21:1301-1321.

32. Jambor JL, Blowes DW, Ritchie AM: Environmental aspects of mine wastes. Mineral Assoc Can Short Course 2003, 31:117-145.

33. Ministerial Order No. 756/1997 approving the Regulation concerning the assessment of environmental pollution. Official Gazette 1997, Romania, Part I, no. 303bis/06.11.1997 [In Romanian].

34. Ministerial Order No. $161 / 2006$ for the approval of the Normative regarding the surface water quality classification in order to establish the ecological status of water bodies. Official Gazette 2006, Part I, no. 511/ 13.06.2006 [In Romanian].

35. Ministerial Order No. 95/2005 for the approval of waste acceptance criteria and national lists of waste accepted in each landfill class. Official Gazette 2005, Part I, no. 194/08.03.2005 [In Romanian].

36. Directive 2006/118/EC of the European Parliament and of the Council of 12 December 2006 on the protection of groundwater against pollution and deterioration. Official Journal of the European Union 2006, L372:19-31.

37. Law No. 137/2009 on Environment Protection. Official Gazette 2006, Part I, no. 511/13.06.2006 [In Romanian]

38. Guidance on groundwater status and trend assessment, Common implementation strategy for the Water Framework (2000/60/EC). Guidance Document No. 18, Technical Report 2009, 26:1-82.

39. Radu E, Balaet R, Vliegenthart F, Schipper P: Derivation of threshold values for groundwater in Romania, in order to distinguish point \&diffuse pollution from natural background levels. Environ Eng Res 2010, 15:85-91.

40. Law No. 458/2002 on the quality of drinking water. Official Gazette 2002 , Part I, no. 857/08.07.2002 [In Romanian].

41. Abollino O, Malandrino M, Giacomino A, Mentasi E: The role of chemometrics in single and sequential extraction assays: a review: part I. Extraction procedures, uni- and bivariate techniques and multivariate variable reduction techniques for pattern recognition. Anal Chim Acta 2011, 688:104-121.
42. Giacomino A, Abollino O, Malandrino O, Mentasti E: The role of chemometrics in single and sequential extraction assays: a review. Part II. Cluster analysis, multiple linear regression, mixture resolution, experimental design and other techniques. Anal Chim Acta 2011, 688:122-139.

43. Gergen I, Harmanescu M: Application of principal component analysis in the pollution assessment with heavy metals of vegetable food chain in the old mining areas. Chem Cent J 2012, 6:156. doi:10.1186/1752-153X-6-156.

44. Zhou F, Guo H, Liu Y, Jiang Y: Chemometrics data analysis of marine water quality and source identification in Southern Hong Kong. Marin Poll Bull 2007, 54:745-756.

45. Lu KL, Liu CW, Jang CS: Using multivariate statistical methods to assess the groundwater quality in an arsenic-contaminated area of Southwestern Taiwan. Environ Monitor Assess 2012, 184:6071-6085.

46. Mannan A: Stratigraphic evolution and geochemistry of the Neogene Surma Group, Surma Basin, Sylhet, Bangladesh. Academic Dissertation 2002, University of Oulu, Department of Geology. http://herkules.oulu.fi/ isbn9514267117/isbn9514267117.pdf.

47. Gonneea ME, Paytan A: Phase association of barium in marine sediments. Marine Chem 2006, 100:124-135.

48. Abreu CA, Cantoni M, Coscione AR, Paz-Ferreiro J: Organic matter and barium absorption by plant species grown in an area polluted with scrap metal residue. Appl Environ Soil Sci 2012, http://dx.doi.org/10.1155/ 2012/476821.

49. Dobran S, Zagury GJ: Arsenic speciation and mobilization in CCAcontaminated soils: Influence of organic matter content. Sci Total Environ 2006, 364:239-250

50. Ponta $\mathrm{M}$, Frentiu $\mathrm{T}$ : Validation of inductively coupled plasma atomic emission spectrometry technique for the determination of trace elements in granular waste. Stud Univ Babes-Bolyai Chem 2012, 57:7-14.

51. Sobek AA, Schuller WA, Freeman JR, Smith RM: Field and laboratory methods applicable to overburdens and minesoils. Cincinnati, Ohio: U.S. Environmental Protection Agency, EPA-600/2-78-054; 1978. http://www.techtransfer.osmre. gov/NTTMainSite/Library/hbmanual/fieldlab/front.pdf

52. US Environmental Protection Agency, Office of Solid Wastes, Special Waste Branch: Acid mine drainage prediction. Washington, DC: Technical Document (EPA530-R-94-036); 1994. http://water.epa.gov/polwaste/nps/upload/amd.pdf.

53. Song Q, Yanful EK: Oxygen influx and geochemistry of percolate water from reactive mine waste rock underlying a sloping channelled soil cover. Appl Geochem 2011, 26:655-665.

\section{doi:10.1186/1752-153X-7-5}

Cite this article as: Levei et al:: Characterization and assessment of potential environmental risk of tailings stored in seven impoundments in the Aries river basin, Western Romania. Chemistry Central Journal 2013 7:5.

Publish with ChemistryCentral and every
scientist can read your work free of charge
"Open access provides opportunities to our
colleagues in other parts of the globe, by allowing
anyone to view the content free of charge."
W. Jeffery Hurst, The Hershey Company.
- available free of charge to the entire scientific community
- peer reviewed and published immediately upon acceptance
- cited in PubMed and archived on PubMed Central
- yours - you keep the copyright
submit your manuscript here:
http://www.chemistrycentral.com/manuscript/

